\title{
C, B, R, or N: The Influence of Related Industry on Terrorists' Choice in Unconventional Weapons
}

\author{
Nicole Tishler \\ Carleton University, Norman Paterson School of International Affairs
}

This study explores which factors, given that a terrorist has crossed the threshold over conventional weapons and into using unconventional ones such as chemical, biological, radiological, and nuclear (CBRN), will determine the likelihood that he/she chooses to use $C, B, R$, or $N$ weapons. Relying primarily on data from the incident-based Monterey WMD Database, it employs multinomial logit regression with $C, B, R$, or $N$ as a categorical dependent variable: a first within the relevant econometric literature. Fundamentally, the study tests the widely-held-although empirically unsubstantiated-technological deterministic assumption that the more readily CBRN technology, materials, and knowledge are accessible to terrorists, the more likely terrorists will be to use unconventional weapons of the corresponding kind: a relationship hypothesized to be stronger for serious attack perpetrators than for hoaxers. Next, the study tests the notion of a continuum of proliferation potential, hypothesizing that as states' regulatory capacity increases, biological terrorism will be most likely and nuclear terrorism will be least likely. Finally, the study assesses variables that have previously been proven as significant determinants of CBRN over conventional terrorism, to provide the groundwork for future evaluation of the extent to which terrorists may be induced to pursue $C, B, R$, or $N$ over conventional weapons.

Keywords: CBRN Terrorism; WMD Terrorism; multinomial logit; technological determinism

Cette étude explore les facteurs, en supposant qu'un terroriste ait franchi le seuil des armes traditionnelles en utilisant des armes non traditionnelles comme les armes chimiques, biologiques, radiologiques et nucléaires (CBRN), qui détermineront la possibilité qu'il/elle choisisse d'utiliser les armes $C, B, R$ ou $N$. En s'appuyant sur des données primaires de la base de données Monterey WMD, elle se sert d'une régression logit multinomial avec $C, B$, $R$ ou $N$ comme une variante dépendante catégorique : il s'agit d'une première pour la documentation pertinente économétrique. Principalement, l'étude vérifie la supposition très répandue - même si elle n'est pas empiriquement corroborée - comme quoi plus la technologie CBRN, les matériaux et les connaissances sont accessibles aux terroristes, plus les terroristes seront portés à se servir d'armes non traditionnelles pour la situation qui s'apprête : une relation censée être plus solide pour des auteurs d'agressions plus dangereuses que pour les charlatans. Ensuite, l'étude vérifie la notion d'une continuité de prolifération éventuelle, en supposant qu'avec l'augmentation de la capacité de réglementation de l'État, le terrorisme biologique serait le plus probable, alors que le terrorisme nucléaire serait le moins probable. Enfin, l'étude évalue les variantes qui ont déjà été prouvées comme déterminant de façon importante les CBRN plutôt que le terrorisme traditionnel, pour fournir un travail préparatoire pour de futures évaluations de l'étendue avec laquelle les terroristes pourraient être incités à se servir d'armes $C, B, R$ ou $N$ plutôt que des armes traditionnelles.

Mots-clés: Terrorisme CBRN, Terrorisme ADM, logit multinomial, déterminisme technologique 


\section{$\underline{\text { Introduction }}$}

Terrorists' interest in — and use of — chemical, biological, radiological and nuclear (CBRN) weapons are increasing. Policy officials and academics alike relate part of this increase to growth in the global spread of technology and materials, as well as dual use knowledge, in scientific research and related chemical, biological (i.e. life sciences and pharmaceuticals), radiological, and nuclear industries. Their fundamental assumption is that this spread in technology and knowledge will make CBRN materials more easily accessible to - and utilized by - a wider range of groups and individuals, including those who will use them with malicious intent. The Government of Canada's (2011) Chemical, Biological, Radiological, Nuclear and Explosives Resilience Strategy for Canada demonstrates no exception: "The prevalence of CBRNE materials in Canadian society for use by industry, in scientific research and medical diagnostics, among other purposes, creates a significant risk of diversion or exploitation by terrorists or criminals" (p. 2).

This study will explore which factors, given that a terrorist has crossed the threshold into using CBRN over conventional weapons, will determine the likelihood that the terrorist will choose to use chemical, biological, radiological, or nuclear (herein referred to as "C, B, R, or N") weapons.

The policy implications of this question are substantial. In Canada, for instance, policy regarding CBRN terrorism is currently aimed at resilience: ensuring that Canada can swiftly and effectively respond in the low-probability, though high-impact, event of a CBRN terrorist attack. If there is a link between the presence of technology and knowledge and the incidence of CBRN terrorism, policymakers may be able to justifiably introduce more preventive measures in terms of counter-proliferation and the control of substances and technological information; counter-CBRN terrorism efforts could be further refined, with resources aimed at areas of high CBRN industrial and scientific productivity, and weak regulation. If there is no link, steps in this direction may unnecessarily constrain industry and research, add regulatory burdens on governments, and ultimately be futile in reducing the CBRN terrorism risk.

\section{$\underline{\text { Literature Review }}$}

The literature on CBRN terrorism is plagued with a paucity of open-source empirical data: not only have few actual CBRN attacks occurred (thankfully), but these events are often coded with incomplete information. The data challenges researchers face when studying CBRN are often addressed explicitly within the literature (see Ackerman, 2009). Koblentz (2011) has even expressed skepticism regarding quantitative methods' potential in CBRN terrorism risk assessment altogether. Most CBRN research is thus derived from general secondary sources on terrorism, or focused on anecdotal case studies. The 1995 sarin gas attacks in Tokyo and the 2001 anthrax attacks in the United States are the usual subjects of these studies. It appears that the only relevant study to have applied a rigorous multi-case methodology addresses only chemical and biological weapons (Tucker, 2000).

A major divide within the literature exists between those who dramatize the risk of CBRN terrorism, usually on the assumed premise that CBRN attacks will increase as technology and knowledge become more globalized in nature, and those who seek to devalue such arguments, usually based on CBRN terrorism's sparse historical record. Still, the historical record shows that many terrorist groups have used and considered using CBRN weapons, and there is seeming near-consensus that technology diffusion will make it easier and, thus, potentially more attractive to pursue CBRN capabilities.

This "technological determinism," a term first developed with respect to nuclear proliferation among states, is carried through to weapon-type-specific analyses (that is, works that focus on only one weapon type: C, B, R, or N). For example, Amy Smithson (2009) explores case study analyses of chemical terrorism, describing the technical advances that may facilitate chemical weapons' proliferation to terrorist groups and lone actors; she specifically notes the industry's growth in the southern hemisphere and suggests that terrorists will become increasingly likely to acquire access to - and knowledge of - chemicals that can be used in attacks. The United States' Committee on Advances in Technology and the Prevention of Their Application to Next Generation Biowarfare Threats (2006) makes a parallel argument with respect to the dispersion of life sciences-related knowledge and technological expertise, and the incidence of biological 
terrorism. Ferguson and Potter (2004) make similar arguments with respect to nuclear terrorism, identifying ways in which terrorists can exploit military and civilian nuclear assets. It should be noted that while Ferguson and Potter's discussion is framed in terms of nuclear terrorism, two of the authors' four scenarios involve the emission or dispersion of radioactive materials (i.e. radiological terrorism), not nuclear explosions (nuclear terrorism).

Technological determinism is mediated by states' capacity to regulate relevant materials and knowledge. To this end, the Committee on Advances in Technology and the Prevention of Their Application to Next Generation Biowarfare Threats (2006) contributes the concept of a "continuum of proliferation potential" (pp. 53-58). According to this continuum, the correlation between the use of a C, B, R, or N weapon and its related technological base is strongest for nuclear terrorism and weakens as one moves to chemical, then radiological, and ultimately biological terrorism, because nonproliferation control regimes become increasingly weak as one progresses along the continuum.

The majority of existing research seeks to distinguish CBRN terrorist events from conventional ones, developing profiles of CBRN attackers and of likely venues. Only a notable few, however, employ econometric techniques. For instance, Coyle (2012) tests whether economic development and political risk indicators commonly used to analyze conventional terrorism apply to CBRN terrorism; and Rowlands, Littlewood, and Kilberg (2012) contribute a set of CBRN-versus-conventional explanatory variables related to terrorist group organizational structure, coded in a dataset developed at Carleton University (Kilberg, 2011). They also describe differences between hoaxes and non-hoaxes, finding that hoaxes are twice as likely to be perpetrated by individuals than by terrorist groups, and that different motivations and group organizational structures - most strongly religious motivation and "hub-spoke" organization - contribute to a group's likelihood to perpetrate hoaxes over serious attacks. Both of these studies include data from the Monterey Weapons of Mass Destruction (WMD) Database (Monterey Terrorism Research and Education Program, 2010) - the most comprehensive open-source data set on CBRN terrorism eventsand the Global Terrorism Database (National Consortium for the Study of Terrorism and Responses to Terrorism, 2011), which includes both conventional and unconventional attacks.

In a project more proximate to this study's aims, Asal, Ackerman and Rethemeyer (2012) explain the incidence of CBRN terrorism using three sets of variables: environmental, organizational, and intrinsic. Among the environmental variables, the level of a host state's technological development (proxied by energy consumption per capita), although hypothesized to be a positive predictor of CBRN terrorism, was found to be insignificant; the authors performed multiple tests to examine if their proxy was simply a poor measure, but they failed to uncover any significant predictors. The degree of the host country's embeddedness in the global economy was a significant positive predictor of CBRN terrorism. The authors concluded that the hypothesized effect of technological development must be incorporated within the economic embeddedness effect; that a globalized and networked world makes a country's level of development unlikely to affect a terrorist's decision to use CBRN weapons.

In their first of two studies, Ivanova and Sandler (2006) use an odds ratio methodology to demonstrate a statistical association between the use of CBRN terrorism and political regime characteristics; group motives and structure; and certain factors relating to target choice. They also produce initial negative binomial regression results, which indicate that regime characteristics can generate causal explanations for the number of CBRN terrorist events a country experiences. Among these characteristics, democracy, strong rule of law, and high wealth (measured as the log of per capita income) are all found to be significant positive determinants of the number of CBRN over conventional attacks. Honesty (the absence of corruption) is found to have a significant negative influence. While each of these variables' coefficients was strongly significant, their magnitudes were of varying practical relevance. Like the studies described above, these authors use data from the Monterey WMD Database for their dependent variable, but they significantly reduce the scope of the database's observations in order to better align with their definition of terrorism and the period under study, which was limited to 1988-2004 due to data availability for their independent variables. Notably, the authors eliminated purely criminally-motivated attacks, along with hoaxes, pranks, and threats where the actors do not actually possess CBRN agents from the sample. 
In a follow-up study, Ivanova and Sandler (2007) introduce three negative binomial regression models to test the direction of causality of their odds ratio findings from the previous year. In addition to their already-tested significant independent variables, the authors investigate whether past CBRN incidents are a determinant of future attacks. Of all the variables examined, they find that past CBRN incidents have the largest marginal impact on the likelihood of future attacks. These findings confirm the notion that once terrorists cross the CBRN threshold, they are likely to continue, due to economies of scale, diminished "setup" costs over time, and the success of their tactics.

This present study contributes to the literature by empirically testing, for the first time, the widely held technological deterministic assumption that CBRN use by terrorists is inevitable, given the spread of technology and knowledge in related fields, and given that existing weapons may be proliferated to terrorist groups. By using a categorical dependent variable (splitting the usual incidence of CBRN terrorism as a unit into the incidence of $\mathrm{C}, \mathrm{B}, \mathrm{R}$, or $\mathrm{N}$ terrorism events considered separately-also a first in the econometric literature), this study nuances Asal, Ackerman and Rethemeyer's (2012) broad-based use of technological development as an explanatory variable for the incidence of CBRN terrorism writ large. In addition to adding five years' worth of observations, this study also presents a refinement to Ivanova and Sandler's $(2006,2007)$ findings that high national wealth increases the likelihood of CBRN terrorism; it may be that per capita income is a confounding or intervening variable, for which the true source is a large C, B, R, or N industry. To this effect, this study rescales Coyle's (2012) application of proven econometric descriptors for conventional terrorism to CBRN terrorism, by testing previously demonstrated determinants of CBRN over conventional weapons across C, B, R, or N outcomes. This study also tests the utility of Ivanova and Sandler's $(2006,2007)$ culling of their dataset, by contributing industry-related variables to Rowlands, Littlewood, and Kilberg's (2012) discussion of the differences between characteristics of hoaxes and non-hoaxes.

\section{Conceptual Framework}

\section{Weapon Type and Related Industry: The Technological Determinist Argument}

The conventional wisdom regarding CBRN terrorism puts forth a widely-accepted assumption to explain variation in terrorists' use of $\mathrm{C}, \mathrm{B}, \mathrm{R}$, or $\mathrm{N}$ weapons: the more readily $\mathrm{C}, \mathrm{B}, \mathrm{R}$, or $\mathrm{N}$ technology, materials, and knowledge are accessible to terrorists, the more likely terrorists will be to use unconventional weapons of the corresponding kind. For instance, a large chemical industrial base in a country would lead to a greater likelihood of chemical terrorism there. Likewise, a country's lack of nuclear technology and knowledge would decrease its likelihood of experiencing nuclear terrorism.

Hypothesis 1A: Terrorist attacks using a particular weapon type will be most likely when the industry corresponding to that weapon within the country of attack is relatively large.

If Hypothesis $1 \mathrm{~A}$ is confirmed, the relationship should be stronger for serious attack perpetrators, who rely on the presence and use of actual CBRN agents, than for hoaxers and pranksters, who are not limited by material constraints.

Hypothesis 1B: Related industry will have a greater influence on the weapon choice of serious attack perpetrators than of hoaxers or pranksters.

\section{Regulatory Capacity and Proliferation Potential}

Based on the notion of a continuum of proliferation potential (Committee on Advances in Technology and the Prevention of Their Application to Next Generation Biowarfare Threats, 2006, pp. 53-58), the correlation between the use of a C, B, R, or N weapon and its related technological base is hypothesized to be strongest for nuclear terrorism and gradually weakens as one moves to chemical, then radiological, and 
ultimately biological terrorism, since industry regulation becomes increasingly difficult as one moves along the continuum. In controlling for states' regulatory capacity, this study will provide insight into the validity of the proliferation continuum hypothesis, while allowing for a ceteris paribus assessment of the effect of $\mathrm{C}, \mathrm{B}, \mathrm{R}$, or $\mathrm{N}$ industry on terrorists' weapon choice.

Hypothesis 2: As states' regulatory capacity increases (decreases), terrorists will most (least) frequently use those CBRN agents that are most (least) difficult to regulate.

\section{Determinants of CBRN Over Conventional Weapons}

In probing the supposed link between industry and related weapon-type, this study provides the groundwork for future evaluation of the extent to which terrorists may be induced to pursue $\mathrm{C}, \mathrm{B}, \mathrm{R}$, or N over conventional weapons. To this end, it includes the variables that are-as demonstrated in previous studies discussed in the literature review-significant determinants of CBRN over conventional terrorism. While it is expected that these variables will have little if any independent effect on the likelihood of $\mathrm{C}, \mathrm{B}, \mathrm{R}$, or $\mathrm{N}$ attacks, a failure to control for them might skew the findings of key explanatory variables.

Hypothesis 3: Regime and perpetrator characteristics previously identified as significant determinants of CBRN over conventional weapons will not be significant determinants of the likelihood of $C, B, R$, or $N$.

This study does not address directly why a terrorist would choose to pursue CBRN over conventional weapons, as such an analysis would require the inclusion of data regarding conventional (i.e. non-CBRN) terrorist attacks. Although doing so would generate wider variation along the dependent variable, it would likely obscure weapon-type-specific nuances, as each of the CBRN weapon types would be dwarfed in relation to the total sample.

\section{The Data}

\section{The Sample and the Dependent Variable: Weapon Type Used in Attack}

This study's unit of analysis is terrorist events in which C, B, R, or N weapons were used; each observation thus represents a $\mathrm{C}, \mathrm{B}, \mathrm{R}$, or $\mathrm{N}$ terrorism incident. To measure the dependent variable-named "weapontype" - this study relies on the incident-based Monterey WMD Database's (Monterey Terrorism Research and Education Program, 2012) coding of primary weapon type, a categorical variable which describes the first attack weapon as biological, chemical, nuclear, radiological, or unknown.

While the Monterey WMD Database contains 1,729 such incidents between 1933 and 2012, the sample used in this study includes 1,431 observations from the period 1990 to 2011. The sample is reduced due to the availability of additional variables, and the removal of observations for which the country of attack and primary weapon type were either un-coded or unknown. The remaining sample, described in Table 1, thus covers a 21-year period (1990-2011), with observations spanning 90 different countries. Since most of the key explanatory variables (described below) are relatively stable within each country from year to year, variation in the type of CBRN weapon used is expected to emerge primarily from differences across countries and attack perpetrators. 
Table 1: Descriptive Statistics for weapontype: $C, B, R$, or $N$

\begin{tabular}{|c|c|c|}
\hline Weapon & Frequency & Percent \\
\hline Biological & 815 & 56.95 \\
\hline Chemical & 482 & 33.68 \\
\hline Nuclear & 42 & 2.94 \\
\hline Radiological & 92 & 6.43 \\
\hline Total & 1,431 & 100.00 \\
\hline
\end{tabular}

Observations are not culled as per Ivanova and Sandler's (2006; 2007) strict requirements. Hoaxes are retained in the sample because "they cause disruption, panic, thicken security barriers and take resources away from other threats" even if they do not involve a "human toll" (Rowlands, Littlewood, and Kilberg, 2012, 34). Criminally-motivated attacks are also retained since they are theoretically no less liable than politically- or ideologically-motivated incidents to generate human tolls, panic, disruption, and security responses. Rowlands, Littlewood, and Kilberg (2012) and Asal, Ackerman, and Rethemeyer (2012) similarly retain criminally-motivated attacks.

\section{Measures of Related Industry}

Measures of CBRN-related industry (summary statistics presented in Appendix, Table A1) are the primary explanatory variables required for testing the technological determinism argument.

Measures of biological industry, bioindustry, and chemical industry, chemindustry, are both sourced from the World Trade Organization's (2012) "Time Series on International Trade." Bioindustry is a continuous variable that measures the value of a country's annual pharmaceutical exports, in US dollars at current prices, as an indicator of a country's domestic production capacity in the life sciences (i.e. "biological" industry) and associated knowledge thereof. Chemindustry is a continuous variable that measures a country's annual chemical exports minus its pharmaceutical exports, also in US dollars at current prices. It serves as a proxy measure for a country's domestic production capacity in the chemical industry and associated knowledge thereof.

Relying on exports as a measure of production capacity presents a major limitation to this data, given that some countries may both produce and use their chemicals and pharmaceuticals domestically; export data will thus understate these countries' production capacity. However, exports are stronger than other trade measures, since including imports (although this would reflect the presence of CBRN agents in a given country) would presumably inflate domestic know-how and technology. Using pharmaceuticals as a proxy for life sciences presents a further challenge. First, pharmaceuticals are actually listed by the World Trade Organization (2012) as a subset of chemical products, and thus-even though they reflect life sciences advancements - are partially correlated with chemical industry advancement. Second, this rather narrow measure is likely to underestimate the true scope and size of biologically-related industry. Furthermore, the World Trade Organization does not distinguish between 0 values (i.e. a country does not export any pharmaceutical or chemical products) and missing values (i.e. the country did not report such exports). As a result, all 0 and missing values have been recorded as missing values in this sample, which may underestimate the influence of a related domestic production capacity, and may also be symptomatic of a structural bias against those few countries that fail to report their exports. Despite these weaknesses, these industry measures are used here since they appear to be the strongest publicly available proxies, covering the widest range of countries and years. Alternate measures, such as data collected for OECD countries, would limit the utility of industry variables in explaining variation in terrorists' choice in weapon, since there is likely little variation in terms of industry size across this group of countries.

Since the sources of radiological terrorism identified by Ferguson and Potter (2004) emanate from nuclear energy facilities, the size of "radiological industry" will be proxied by radindustry: a continuous, 
absolute measure in kilowatt-hours of a country's annual nuclear electricity production, as measured by the World Bank's (2012) "World Development Indicators." The employment of electricity production rather than electricity use emphasizes a country's domestic production capacity and associated knowledge thereof, rather than mere presence of agents. Unfortunately, a more precise or alternate measure of "radiological industry" is impossible to quantify exhaustively, given that radioactive materials can be acquired in varying quantities from such wide-ranging sources as hospitals, science labs, and even every-day commodities such as tritium exit signs. Nuclear "industry," nuclearindustry, is proxied by a dummy variable that differentiates countries that possess weapons-usable nuclear materials from those that do not, as identified by the Nuclear Threat Initiative (NTI)'s (2012) "Nuclear Materials Security Index."

\section{Measures of States' Regulatory Capacity}

Two variables are used to measure a state's capacity to regulate or control C, B, R, or N industries (summary statistics presented in Appendix, Table A2). The first, industryreg, is the NTI's (2012) coding, on a scale of 0 to 100, of the degree to which countries have implemented United Nations Security Council Resolution (UNSCR) 1540, which obliges states to implement domestic legislation regarding WMD materials security. While this measure only exists as of UNSCR 1540's pronouncement in 2004, industryreg is applied here as a standard score per country since 1990, since it is likely that the resolution's implementation reflects a pre-existing commitment to WMD materials security and state capacity to that effect.

The second proxy measure is the Political Risk Services Group's (2012) "International Country Risk Guide" coding of bureaucratic quality, bureauqual. Measured on a four-point scale, bureauqual reflects the strength of a country's bureaucracy and its capacity to withstand governmental changes and maintain political autonomy. A limitation to the bureauqual measure is that it pertains only to a general quality of states that is likely to affect the state's regulatory capacity; it is not linked directly to regulation or any specific industries. It is used nonetheless, since it captures variation within countries over time, which the industry-specific industryreg measure does not.

\section{Measures of Previously-Identified Controls}

These variables (summary statistics presented in Appendix, Table A3) have been collected based on previous studies' findings and, where possible, using the same sources (summarized in Appendix, Table A4).

Country-specific controls— $-g d p p c$ and techdev — are sourced from the World Bank's (2012) "World Bank Development Indicators." Gdppc, as a proxy for a country's overall wealth, measures a country's GDP per capita in thousands of constant 2000 US dollars, for the country and year in which an attack occurred. Techdev, as a proxy of a country's technological development, measures total energy consumption (megagrams of oil equivalent) per capita, in the country and year of attack.

Regime-specific controls measure levels of democracy (polity2) and corruption (corruption). Polity2 is the Polity Project's (Marshall and Jaggers 2011) "revised combined polity score." An ordinal variable with values ranging from -10 to +10 , it represents a sum of Polity's "institutionalized democracy" and "institutionalized autocracy" scores. Corruption is an ordinal variable with values ranging from 0 to 6 , as coded by the Political Risk Services Group's (2012) "International Country Risk Guide." It measures corruption within a state's political system, emphasizing actual or potential nepotism, overinvolved patronage, secret funding deals, and suspicious links between business and politics.

Two perpetrator-specific variables are coded. Religious motivation, religious, is a dummy variable - coded here by Kilberg (2011) — that identifies those attacks perpetrated by religiously-motivated terrorist groups. Transnational orientation, transnational, is a dummy variable that identifies those attacks perpetrated by transnationally-oriented (as opposed to domestically-oriented) terrorist groups. It is coded here according to the method prescribed in Ivanova and Sandler (2007): if the perpetrator group is also identified in the "International Terrorism: Attributes of Terrorist Events (ITERATE): 1968-2006" dataset (Mickolus et al., 2006), it is assumed to have a transnational orientation and thus coded as 1 . If the 
perpetrator group is not named in ITERATE, or if the perpetrator is a lone wolf or unidentified, it is coded as 0.

\section{Econometric Models and Estimation Methods}

A multinomial logit regression is employed to test the influence of the above-defined independent variables, described in Table 2, on the categorical dependent variable, weapontype. Here, the variables predict the likelihoods of four possible, non-orderable, nominal outcomes- $\mathrm{C}, \mathrm{B}, \mathrm{R}$, or $\mathrm{N}$ terrorism incidents-relative to a base outcome. In this study, unless otherwise specified, the base outcome used for interpretation and the presentation of results is biological incidents. Since each outcome in a multinomial logit regression signifies its likelihood relative to a given base outcome, the model's "coefficients" are presented as relativerisk ratios (RRRs). The RRR illustrates the influence of the explanatory variable on the likelihood of an outcome relative to the base case.

Two general multinomial logit models are tested. Model 1 addresses measures of states' regulatory capacity $\left(x_{5}\right.$ and $\left.x_{6}\right)$, and characteristics specific to perpetrators ( $x_{7}$ and $\left.x_{8}\right)$, regimes $\left(x_{3}\right.$ and $\left.x_{4}\right)$, and countries $\left(x_{1}\right.$ and $\left.x_{2}\right)$ that have been previously identified as determinants of CBRN over conventional terrorism:

$$
\begin{aligned}
& \text { weapontype }=\beta_{0}+\beta_{1} \text { gdppc }_{1}+\beta_{2} \text { techde }_{2}+\beta_{3} \log \left(\text { polity }_{2}\right)_{3}+\beta_{4} \text { corruption }_{4}+ \\
& \beta_{5} \text { bureauqual }_{5}+\beta_{6} \text { industryreg }_{6}+\beta_{7} \text { transnational }_{7}+\beta_{8} \text { religious }_{8}+\mu
\end{aligned}
$$

Model 2 adds industry-specific variables $\left(x_{9}, x_{10}\right.$ and $\left.x_{11}\right)$ to the previous model:

$$
\begin{aligned}
& \text { weapontype }=\beta_{0}+\beta_{1} \text { gdppc }_{1}+\beta_{2} \text { techde }_{2}+\beta_{3} \log \left({\text { polity } 2)_{3}}_{3}+\beta_{4} \text { corruption }_{4}+\right. \\
& \beta_{5} \text { bureauqual }_{5}+\beta_{6} \text { industryreg }_{6}+\beta_{7 \text { transnational }_{7}}+\beta_{8} \text { religious }_{8}+ \\
& \beta_{9 \text { nuclearindustryg }}+\beta_{10} \log (\text { chemindustry/bioindustry })_{10}+ \\
& \beta_{11}(\text { radindustry/bioindustry })_{11}+\mu
\end{aligned}
$$

These models include most variables in their absolute form described in the previous section, except for polity 2 and the two industry ratios. The log of polity 2 is taken to narrow the variable's range, and make it less sensitive to an abundance of high scores (72.83\% of observations scored 10 in polity 2$)$. Instead of absolute measures of industry size, ratios are taken of both radindustry and chemindustry to bioindustry to capture variation across countries regarding industries' relative sizes within them. Bioindustry is used as the denominator in both cases to produce estimates that are less sensitive to extreme high values of the chemindustry variable.

Models 1 and 2 are each tested against two forms of the weapontype dependent variable: one in which there are four categories, C, B, R, or N (Models $\mathbf{1 A}$ and $\mathbf{2 A}$ ); and one in which R and $\mathrm{N}$ are collapsed into a single category (Models 1B and 2B). The logic for doing so is two-fold. From a practical perspective, there is no publicly available codebook for the Monterey WMD Database that could define how nuclear and radiological attacks were coded. Within the available literature, radiological terrorism is understood to refer to the dispersion of radioactive materials, and nuclear terrorism is understood to mean terrorists' use of nuclear fusion or fission to produce an atomic implosion or explosion. The Monterey WMD Database's inclusion of "nuclear" as an outcome with 42 observations is thus suspect, since in none of these cases did a nuclear incident, according to the conventional understanding of the term, take place. From a theoretical standpoint, it is possible that the available proxy variables, radindustry and nuclearindustry, will not clearly distinguish between nuclear and radiological "industry," since they both pertain to a country's nuclear energy production capacity. 
Vol. 2, Iss/Num. 2, Fall/Automne 2013

Table 2: Variable Descriptions

\begin{tabular}{|c|c|}
\hline weapontype & $\begin{array}{l}\text { type of weapon used in terrorism incident; either with four outcomes }(C, B \text {, } \\
R \text {, or } N) \text { or three outcomes, with radiological and nuclear combined }(C, B \text {, or } \\
R+N)\end{array}$ \\
\hline bioindustry & $\begin{array}{l}\text { annual pharmaceutical exports, in US dollars at current prices, per country } \\
\text { and year of terrorism incident; a proxy for the country's life sciences (i.e. } \\
\text { "biological") industry }\end{array}$ \\
\hline chemindustry & $\begin{array}{l}\text { annual chemical exports minus pharmaceutical exports (if reported), in US } \\
\text { dollars at current prices, per country and year of terrorism incident; a proxy } \\
\text { for the country's chemical industry }\end{array}$ \\
\hline nuclearindustry & $\begin{array}{l}=1 \text { if target country possesses weapons-usable materials, } 0 \text { otherwise; a } \\
\text { proxy for the country's nuclear "industry" }\end{array}$ \\
\hline radindustry & $\begin{array}{l}\text { annual electricity production from nuclear sources, in kilowatt-hours, per } \\
\text { country and year of terrorism incident; a proxy for the country's radiological } \\
\text { industry }\end{array}$ \\
\hline $\begin{array}{l}\log (\text { chemindustry } \\
\text { /bioindustry) }\end{array}$ & $\begin{array}{l}\text { log of chemindustry divided by bioindustry; log transformation allows } \\
\text { relative-risk ratio to serve as elasticity of weapontype with respect to this } \\
\text { ratio; a measure of chemical industry's size relative to biological industry }\end{array}$ \\
\hline $\begin{array}{l}\text { (radindustry } \\
\text { /bioindustry) }\end{array}$ & $\begin{array}{l}\text { radindustry divided by bioindustry; a measure of radiological industry's size } \\
\text { relative to biological industry }\end{array}$ \\
\hline bureauqual & $\begin{array}{l}\text { scale coding ( } 0-4) \text { of target country's bureaucratic strength and its } \\
\text { bureaucracy's capacity to withstand governmental changes and maintain } \\
\text { political autonomy in the year of attack; a proxy for states' industrial } \\
\text { regulatory capacity }\end{array}$ \\
\hline industryreg & $\begin{array}{l}\text { scale coding (1-100) of the degree to which countries have implemented } \\
\text { UNSCR } 1540 \text {, current values; a proxy measure for states' CBRN industry } \\
\text { regulation }\end{array}$ \\
\hline$g d p p c$ & $\begin{array}{l}\text { GDP per capita in } \$ 1000 \text { of dollars per country and year of attack, in } \\
\text { constant } 2000 \text { US dollars; a measure of country wealth }\end{array}$ \\
\hline techdev & $\begin{array}{l}\text { total energy consumption (megagram of oil equivalent) per capita, for } \\
\text { country and year of attack; a proxy for level of technological development in } \\
\text { target country }\end{array}$ \\
\hline corruption & $\begin{array}{l}\text { ordinal ( } 0 \text { to } 6) \text { ranking of corruption within political system, per country } \\
\text { and year of attack }\end{array}$ \\
\hline $\log ($ polity 2$)$ & $\begin{array}{l}\text { log of polity2 ("Revised Combined Polity Score"), an ordinal variable (-10 } \\
\text { to }+10 \text { ) measuring autocracy (negative values) and democracy (positive } \\
\text { values) for country and year of attack; log transformation allows relative- } \\
\text { risk ratio to serve as elasticity of weapontype with respect to polity } 2\end{array}$ \\
\hline religious & $\begin{array}{l}=1 \text { if perpetrator is an identified terrorist group with religious motivation, } 0 \\
\text { otherwise }\end{array}$ \\
\hline transnational & $\begin{array}{l}=1 \text { if perpetrator is an identified terrorist group with transnational } \\
\text { orientation, } 0 \text { otherwise }\end{array}$ \\
\hline
\end{tabular}


Models 1 and 2 are each tested against two forms of the weapontype dependent variable: one in which there are four categories, $\mathrm{C}, \mathrm{B}, \mathrm{R}$, or $\mathrm{N}$ (Models 1A and 2A); and one in which R and $\mathrm{N}$ are collapsed into a single category (Models 1B and 2B). The logic for doing so is two-fold. From a practical perspective, there is no publicly available codebook for the Monterey WMD Database that could define how nuclear and radiological attacks were coded. Within the available literature, radiological terrorism is understood to refer to the dispersion of radioactive materials, and nuclear terrorism is understood to mean terrorists' use of nuclear fusion or fission to produce an atomic implosion or explosion. The Monterey WMD Database's inclusion of "nuclear" as an outcome with 42 observations is thus suspect, since in none of these cases did a nuclear incident, according to the conventional understanding of the term, take place. From a theoretical standpoint, it is possible that the available proxy variables, radindustry and nuclearindustry, will not clearly distinguish between nuclear and radiological "industry," since they both pertain to a country's nuclear energy production capacity.

Finally, the more comprehensive Model 2 is tested against two subsets of observations: hoaxes and pranks (Model 2C) versus only "serious" terrorism incidents (Model 2D). The latter is tested using the four-outcome dependent variable based on the findings of Models 1A, 1B, 2A, and 2B (discussed below), which demonstrate meaningful differences between terrorists' choice of radiological or nuclear weapons. Model 2C is tested using a general logit regression with only two dependent variable outcomes: biological and chemical. Radiological and nuclear incidents were dropped from the sample, as their low frequency1 and 3 observations respectively-prevented the application of a multinomial logit regression. Tests indicate that the models do not exhibit any significant heteroskedasticity or multicollinearity.

\section{$\underline{\text { Results and Analysis }}$}

\section{Findings Across Differing Arrangements of the Dependent Variable}

Models 1A, 1B, 2A and 2B yielded robust results. Given the degree to which human agency can be assumed to play a role in terrorists' weapon choice, the models' explanatory power - pseudo r-squared at 0.177 , 0.179, 0.201, and 0.197 respectively - is fairly high. Results for Models 1A and 2A, with the dependent variable weapontype comprising four categories - $\mathrm{C}, \mathrm{B}, \mathrm{R}$, or $\mathrm{N}$-are presented in Table 3. Results for Models 1B and 2B - with three weapontype categories, C, B, or $\mathrm{R}+\mathrm{N}$-are presented in Table 4.

\section{Hypothesis 1: Weapon Type and Related Industry}

The data provide mixed support for the technological determinist hypothesis. In distinguishing between chemical and biological incidents, the results are compelling: in Model 2A, a one unit increase in $\log$ (chemindustry/bioindustry) results in a $42.1 \%$ (42.5\% in Model 2B) increase in the likelihood of a chemical attack as opposed to a biological one. The practical significance of this value is quite large, given the variable's statistical dispersion: a country with the highest logged ratio will be nearly four and a half times more likely to experience chemical attacks over biological ones than a country with the smallest proportion of biological to chemical industry.

The data are less clear with respect to nuclear and radiological terrorism. The radindustry/bioindustry ratio only approached significance $(\mathrm{p}=0.073)$ for radiological incidents in Model 2A. Additionally, at 1.002, the RRR bears little practical significance (only 0.002\%) in determining the likelihood of radiological over biological terrorism. 
Vol. 2, Iss/Num. 2, Fall/Automne 2013

Table 3: Multinomial Logit Regression Results for Weapon Type-C, B, R, or $N$

\begin{tabular}{|c|c|c|c|c|c|}
\hline \multirow[b]{2}{*}{ DV } & \multirow[b]{2}{*}{ Independent Variable } & \multicolumn{2}{|c|}{ Model 1A } & \multicolumn{2}{|c|}{ Model 2A } \\
\hline & & $\begin{array}{c}\text { Relative-Risk } \\
\text { Ratio }\end{array}$ & P-Value & $\begin{array}{c}\text { Relative-Risk } \\
\text { Ratio }\end{array}$ & P-Value \\
\hline \multicolumn{6}{|c|}{ BIOLOGICAL INCIDENT (Base Outcome) } \\
\hline \multirow{12}{*}{ 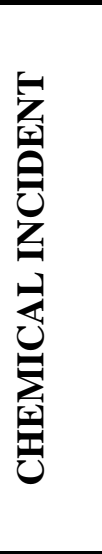 } & $g d p p c$ & 0.980 & 0.145 & 0.928 & 0.000 \\
\hline & techdev & 0.876 & 0.015 & 0.836 & 0.005 \\
\hline & $\log ($ polity 2$)$ & 1.638 & 0.341 & 6.453 & 0.014 \\
\hline & corruption & 1.888 & 0.000 & 1.382 & 0.028 \\
\hline & bureauqual & 0.543 & 0.007 & 0.861 & 0.614 \\
\hline & industryreg & 0.997 & 0.723 & 1.001 & 0.963 \\
\hline & transnational & 8.741 & 0.000 & 8.471 & 0.000 \\
\hline & religious & 4.064 & 0.000 & 3.906 & 0.002 \\
\hline & nuclearindustry & & & 6.422 & 0.000 \\
\hline & $\log$ (chemindustry/bioindustry) & & & 1.421 & 0.028 \\
\hline & radindustry/bioindustry & & & 0.998 & 0.116 \\
\hline & Constant & 0.444 & 0.389 & 0.007 & 0.001 \\
\hline \multirow{12}{*}{ 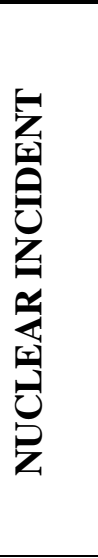 } & $g d p p c$ & 0.976 & 0.586 & 0.993 & 0.911 \\
\hline & techdev & 0.942 & 0.716 & 0.870 & 0.537 \\
\hline & $\log ($ polity 2$)$ & 0.576 & 0.507 & 2.084 & 0.667 \\
\hline & corruption & 1.496 & 0.227 & 1.459 & 0.380 \\
\hline & bureauqual & 0.269 & 0.008 & 0.154 & 0.010 \\
\hline & industryreg & 1.026 & 0.247 & 1.033 & 0.260 \\
\hline & transnational & 3.638 & 0.017 & 3.314 & 0.069 \\
\hline & religious & 5.543 & 0.054 & 5.186 & 0.091 \\
\hline & nuclearindustry & & & 2.932 & 0.262 \\
\hline & $\log ($ chemindustry/bioindustry) & & & 0.008 & 0.983 \\
\hline & radindustry/bioindustry & & & 0.999 & 0.636 \\
\hline & Constant & 0.619 & 0.790 & 0.064 & 0.464 \\
\hline \multirow{12}{*}{ 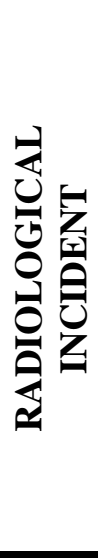 } & $g d p p c$ & 1.035 & 0.185 & 1.022 & 0.554 \\
\hline & techdev & 0.706 & 0.001 & 0.629 & 0.000 \\
\hline & $\log ($ polity 2$)$ & 0.261 & 0.044 & 5.504 & 0.277 \\
\hline & corruption & 0.552 & 0.012 & 0.365 & 0.000 \\
\hline & bureauqual & 0.866 & 0.684 & 1.550 & 0.394 \\
\hline & industryreg & 1.037 & 0.023 & 1.018 & 0.468 \\
\hline & transnational & 4.300 & 0.000 & 3.216 & 0.029 \\
\hline & religious & 3.826 & 0.021 & 5.552 & 0.008 \\
\hline & nuclearindustry & & & 2.785 & 0.148 \\
\hline & $\log$ (chemindustry/bioindustry) & & & 1.071 & 0.798 \\
\hline & radindustry/bioindustry & & & 1.002 & 0.073 \\
\hline & Constant & 3.640 & 0.325 & 0.007 & 0.150 \\
\hline & Number of observations & \multicolumn{2}{|c|}{1246} & \multicolumn{2}{|c|}{1106} \\
\hline & Prob $>$ chi-squared & \multicolumn{2}{|c|}{0.0000} & \multicolumn{2}{|c|}{0.0000} \\
\hline & Pseudo r-squared & \multicolumn{2}{|c|}{0.177} & \multicolumn{2}{|c|}{0.201} \\
\hline & Log likelihood & \multicolumn{2}{|c|}{-938.239} & \multicolumn{2}{|c|}{-765.723} \\
\hline
\end{tabular}


Vol. 2, Iss/Num. 2, Fall/Automne 2013

Table 4:Multinomial Logit Regression Results for Weapon Type $=C, B, R$ or $N$

\begin{tabular}{|c|c|c|c|c|c|}
\hline \multirow[b]{2}{*}{ DV } & \multirow[b]{2}{*}{ Independent Variable } & \multicolumn{2}{|c|}{ Model 1A } & \multicolumn{2}{|c|}{ Model 2A } \\
\hline & & \begin{tabular}{|c|} 
Relative-Risk \\
Ratio
\end{tabular} & P-Value & $\begin{array}{c}\text { Relative-Risk } \\
\text { Ratio }\end{array}$ & P-Value \\
\hline \multicolumn{6}{|c|}{ BIOLOGICAL INCIDENT (Base Outcome) } \\
\hline \multirow{12}{*}{ 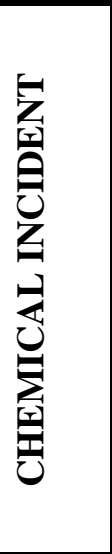 } & $g d p p c$ & 0.980 & 0.145 & 0.928 & 0.000 \\
\hline & techdev & 0.876 & 0.015 & 0.836 & 0.005 \\
\hline & $\log ($ polity 2$)$ & 1.638 & 0.341 & 6.453 & 0.014 \\
\hline & corruption & 1.888 & 0.000 & 1.382 & 0.028 \\
\hline & bureauqual & 0.543 & 0.007 & 0.861 & 0.614 \\
\hline & industryreg & 0.997 & 0.723 & 1.001 & 0.963 \\
\hline & transnational & 8.741 & 0.000 & 8.471 & 0.000 \\
\hline & \begin{tabular}{|l|} 
religious \\
\end{tabular} & 4.064 & 0.000 & 3.906 & 0.002 \\
\hline & nuclearindustry & & & 6.422 & 0.000 \\
\hline & $\log (\mathrm{chemindustry/bioindustry)}$ & & & 1.421 & 0.028 \\
\hline & radindustry/bioindustry & & & 0.998 & 0.116 \\
\hline & Constant & 0.444 & 0.389 & 0.007 & 0.001 \\
\hline \multirow{12}{*}{ 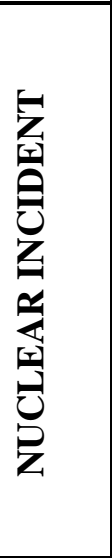 } & $g d p p c$ & 0.976 & 0.586 & 0.993 & 0.911 \\
\hline & techdev & 0.942 & 0.716 & 0.870 & 0.537 \\
\hline & $\log ($ polity 2$)$ & 0.576 & 0.507 & 2.084 & 0.667 \\
\hline & corruption & 1.496 & 0.227 & 1.459 & 0.380 \\
\hline & bureauqual & 0.269 & 0.008 & 0.154 & 0.010 \\
\hline & industryreg & 1.026 & 0.247 & 1.033 & 0.260 \\
\hline & transnational & 3.638 & 0.017 & 3.314 & 0.069 \\
\hline & religious & 5.543 & 0.054 & 5.186 & 0.091 \\
\hline & nuclearindustry & & & 2.932 & 0.262 \\
\hline & $\log$ (chemindustry/bioindustry) & & & 0.008 & 0.983 \\
\hline & radindustry/bioindustry & & & 0.999 & 0.636 \\
\hline & Constant & 0.619 & 0.790 & 0.064 & 0.464 \\
\hline \multirow{12}{*}{ 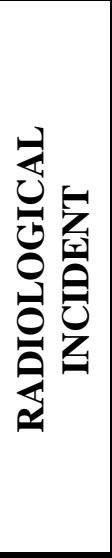 } & $g d p p c$ & 1.035 & 0.185 & 1.022 & 0.554 \\
\hline & techdev & 0.706 & 0.001 & 0.629 & 0.000 \\
\hline & $\log ($ polity 2$)$ & 0.261 & 0.044 & 5.504 & 0.277 \\
\hline & corruption & 0.552 & 0.012 & 0.365 & 0.000 \\
\hline & bureauqual & 0.866 & 0.684 & 1.550 & 0.394 \\
\hline & industryreg & 1.037 & 0.023 & 1.018 & 0.468 \\
\hline & transnational & 4.300 & 0.000 & 3.216 & 0.029 \\
\hline & religious & 3.826 & 0.021 & 5.552 & 0.008 \\
\hline & nuclearindustry & & & 2.785 & 0.148 \\
\hline & $\log$ (chemindustry/bioindustry) & & & 1.071 & 0.798 \\
\hline & radindustry/bioindustry & & & 1.002 & 0.073 \\
\hline & Constant & 3.640 & 0.325 & 0.007 & 0.150 \\
\hline & Number of observations & \multicolumn{2}{|c|}{1246} & \multicolumn{2}{|c|}{1106} \\
\hline & Prob > chi-squared & \multicolumn{2}{|c|}{0.0000} & \multicolumn{2}{|c|}{0.0000} \\
\hline & Pseudo r-squared & \multicolumn{2}{|c|}{0.177} & \multicolumn{2}{|c|}{0.201} \\
\hline & Log likelihood & \multicolumn{2}{|c|}{-938.239} & \multicolumn{2}{|c|}{-765.723} \\
\hline
\end{tabular}


The indicator nuclearindustry generated unexpected results: in Model 2A, it was not a significant determinant of nuclear or radiological incidents with any base outcome, but it did have a surprisingly strong effect $(\mathrm{RRR}=6.421)$ on the likelihood of chemical over biological terrorism. That is, the presence of weapons-usable nuclear materials in a country made chemical terrorism nearly five and a half times more likely than biological terrorism. In Model 2B, nuclearindustry was significant for chemical weapons (RRR $=6.292)$ and the nuclear-radiological combination $(\mathrm{RRR}=3.205)$, demonstrating that both chemical and nuclear or radiological attacks are more likely than biological attacks when a country possesses nuclear weapons-usable materials.

While stronger proxy measures for radiological and nuclear industry would be required to conclusively confirm or disconfirm Hypothesis 1A, the findings for $\log$ (chemindustry/bioindustry) indicate that terrorists' choice in weapon is, at least in some cases, linked to related industrial capacity.

\section{Hypothesis 2: Regulatory Capacity and Proliferation Potential}

The models generate convincing support for Hypothesis 2 regarding a continuum of proliferation potential and states' regulatory capacity. In Model 1A, bureauqual is significant and with the smallest RRR $(=0.269)$ for nuclear industry (note that when RRR $<1$, the closer it is to 0 , the larger its negative likelihood of occurring). The RRR is even closer to $0(\mathrm{RRR}=0.154$ ) when controlling for Model 2A's industry variables. As states' bureaucratic quality increases, nuclear attacks thus retain only between 15.4 and 26.9 percent chances of occurring, relative to biological attacks, which - assuming the order of proliferation potential in the continuum is accurate (i.e. biological agents are most difficult to regulate, and nuclear agents are most easily regulated) - confirms the hypothesis that higher state regulatory capacity corresponds to the use of the most difficultly regulated CBRN agents.

Bureauqual is significant with a moderately-sized, smaller-than-one RRR (0.543) for chemical incidents in Model 1A, thus placing chemical terrorism accurately on the continuum between the poles of biological and nuclear. While bureauqual does not generate significant coefficients for radiological attacks with biological as the regression's base outcome (implying that it is not statistically different from biological, and thus - as the hypothesis suggests - difficult to regulate), when the base case is switched to radiological (i.e. when RRRs are made to represent relationships between the corresponding weapon type and radiological incidents), a significant bureauqual coefficient for nuclear incidents demonstrates that radiological terrorism would lie close to biological (toward the "difficult to regulate" pole) on the continuum. When nuclear and radiological incidents are collapsed into a single category, Model 1B also demonstrates that biological agents are more difficult to regulate than chemical agents. The insignificant coefficient for the combination of radiological and nuclear incidents provides implicit support for Hypothesis 2, since radiological and nuclear agents are not adjacent to one another on the proliferation continuum; their combined relationship relative to the other two weapon types should be ambiguous if the continuum and hypothesis are correct.

\section{Hypothesis 3: Determinants of CBRN Over Conventional Weapons}

Contrary to the expectations of Hypothesis 3, some of the regime and perpetrator characteristics previously identified as significant determinants of CBRN over conventional terrorism were not only significant, but with large magnitudes.

Most notably, perpetrator characteristics - transnational and religious-were consistently, across nearly all dependent variable outcomes in Models 1A, 1B, 2A, and 2B, statistically significant and with RRRs ranging from 3.104 (transnational for nuclear incidents in Model 2B) to 8.753 (transnational for chemical incidents in Model 1B). While there was slight variation between models and across $\mathrm{C}, \mathrm{B}, \mathrm{R}$, or $\mathrm{N}$ outcomes regarding which of the two perpetrator variables had the strongest influence on terrorist's choice in weapon, a clear trend emerged: both transnationally-oriented and religiously-motivated terrorists were significantly less likely to employ biological weapons than other weapon types. 
The low likelihood of transnationally-oriented groups to pursue biological terrorism can be linked with the proliferation continuum, and lends support to the technological determinist hypothesis. Since biological agents are difficult to regulate, they are presumably more prevalent in a wider range of states and more readily available to actors within these states. Transnational terrorist groups, however, "are in a more competitive news market than domestic terrorists and this induces [them] to seek more ghastly actions" (Ivanova and Sandler, 2007, p. 282). While Ivanova and Sandler make this claim to support a hypothesis that transnational terrorists would be more inclined to pursue CBRN over conventional weapons, such competition for media attention might produce a disincentive toward using biological weapons, since they are presumably the most common CBRN weapon type (comprising 56.95\% of all observations).

The available literature does not appear to present any meaningful reason for which religiouslymotivated terrorists would be unlikely to pursue biological terrorism. In fact, this result runs contrary to experience with Al Qaeda, arguably the best-known religious and transnational terrorist group: before his death, Osama bin Laden had pursued the development of unconventional weapons - including, supposedly, biological weapons - as "a religious duty" (as cited in Yusufzai, 1999). It is likely that the above-described findings regarding religious groups and biological terrorism result from a confounding factor: the high prevalence of biological hoaxes in the sample, and the high likelihood that religious terrorists will perpetrate serious attacks more often than hoaxes. Biological incidents comprised 93.82\% (729 of 777) of hoaxes, compared with $13.15 \%$ ( 86 of 654 ) of serious attacks; and religious-motivated terrorists perpetrated only $0.65 \%$ (5 of 768) of hoaxes, compared with $15.90 \%$ (104 of 550) of serious attacks. Since hoaxes are very likely to be biological, and religious-motivated terrorists are less likely to perpetrate hoaxes than serious attacks, it misleadingly appears that religious-motivated terrorists are unlikely to use biological weapons. Indeed, when hoaxes and pranks are controlled for (i.e. a hoax or prank indicator is added to Model 2), the significance of the coefficients for religious in every case is eliminated. Transnational, on the other hand, remains robust, and so the spurious argument does not challenge the above-described relationship with respect to transnational terrorists.

The RRRs for $g d p p c$ are also of note. In Model 2A, a smaller-than-one RRR of $g d p p c$ for chemical relative to biological incidents (0.928) suggests that biological is more likely than chemical terrorism when country wealth is high. When the base outcome is switched to chemical, radiological becomes $10 \%$ more likely than chemical terrorism when country wealth is high. This relationship between both biological and radiological incidents and high $g d p p c$ may be highlighting a weakness of the related industry measures: since life sciences or "biological industry" in addition to radiological capacity can be presumed to be generally more advanced in richer countries, it is possible that gdppc may be capturing the effects of related industries that this study's limited industry proxies fail to encompass.

Overall, the surprising statistical significance of many previously-identified determinants of CBRN over conventional weapons in determining $\mathrm{C}, \mathrm{B}, \mathrm{R}$, or $\mathrm{N}$ suggests that treating $\mathrm{CBRN}$ as a general category may obscure important differences regarding the determinants of unconventional weapon type use.

\section{Hypothesis 1 Revisited: Hoaxes and Pranks versus Serious Attacks}

When separating hoaxes and pranks from serious attacks (results presented in Appendix, Table A5), the industry explanatory variables of Model 2, based on pseudo r-squared values, performed better for hoaxes than for non-hoaxes. While the comparison between the two models is not perfect, given that only two weapon types were assessed in the hoax sample, it generates results consistent with Rowlands, Littlewood, and Kilberg's (2012) findings that CBRN hoaxes are most likely to be biological, and actual attacks are most often chemical. That industry and regulation variables lack significance for all types of serious attack suggests that terrorists are not induced to actually employ particular weapons simply because they are more easily-accessed, nor are they dissuaded by difficulty in access imposed by regulation: those who aspire to perpetrate serious CBRN incidents will actively seek the weapon type they desire. While Hypothesis 1A is confirmed for the entire sample including hoaxes and serious attacks (since the former are more predominant in the sample than the latter), its null hypothesis cannot be rejected for serious attack perpetrators on their own. 
While perpetrators of hoaxes and pranks appear quick to "imagine away" potential regulatory barriers (both bureauqual and industryreg are significant and positive predictors of chemical over biological incidents, contrary to the earlier findings of a proliferation continuum in the alternate direction), they are less imaginative when it comes to the type of weapon they imitate: with every $100 \%$ increase in $\log$ (chemindustry/bioindustry) - that is, as chemindustry becomes increasingly large relative to bioindustry - the likelihood of a chemical over biological hoax or prank increases by more than three and a half $(\mathrm{RRR}=4.573)$ times. The data thus support the alternate hypothesis to $1 \mathrm{~B}$ : related industry has a greater influence on the weapon choice of hoaxers and pranksters than of serious attack perpetrators. In other words, the widely held technological deterministic hypothesis, while seemingly false for perpetrators of serious attacks, appears to be internalized by hoaxers and pranksters who may draw on the availability of technology and knowledge to make their claims and acts more believable.

That such counterintuitive results - with important policy implications - are found when the total sample of observations includes hoaxes and pranks in addition to serious attacks casts serious doubt on the utility of Ivanova and Sandler's (2006; 2007) culling of the Monterey dataset. Especially given that policy responses are initiated whether or not a supposed terrorist attack is eventually uncovered as a hoax, it is imperative for future study to uncover any systematic differences that might assist in the early identification of which "attacks" are hoaxes, and which may go on to exact a human toll; such inferences cannot be drawn from a sample of serious attacks alone.

\section{Conclusions}

This study has demonstrated that the technological determinism hypothesis holds only under certain circumstances. For serious attack perpetrators, the null hypothesis cannot be rejected. For perpetrators of hoaxes and pranks, and within the broader sample of all CBRN incidents, the hypothesis holds strongly with respect to chemical and biological weapons. The fortunate lack of existing empirical evidence precludes the extension of this finding to radiological and nuclear hoaxes. Stronger proxy measures for radiological and nuclear industry - as well as a greater frequency of radiological and nuclear hoaxeswould be required for the technological determinist hypothesis for all CBRN categories to be conclusively assessed. Given the degree to which present policy in Canada and other countries is premised on the technological determinism hypothesis, such further study is necessary. While measures for chemical and biological industry appear to perform well, findings for the effect of country wealth, gdppc, suggest that pharmaceutical exports as a proxy for life sciences (i.e. biological) industry may underestimate the size of a country's true "biological" industry, and thus exaggerate findings for ratios using this measure as a denominator.

Regression results for the entire sample support the hypothesis of a continuum of proliferation potential, with biological being the most difficult to regulate, followed by radiological, chemical, and nuclear proliferation: biological weapons are the most - and nuclear the least-likely weapons to be used when a state's regulatory capacity is high. The hypothesis does not, however, hold for the sample of serious attacks only, suggesting that terrorists who aspire to perpetrate serious CBRN incidents will actively seek the weapon type they desire, irrespective of regulatory constraints and ease of access.

The study also finds significant results for regime and perpetrator characteristics previously identified as significant determinants of CBRN over conventional weapons when applied to the likelihood of $\mathrm{C}, \mathrm{B}, \mathrm{R}$, or $\mathrm{N}$. The most notable of these characteristics are country wealth and perpetrator groups' transnational orientation. These findings suggest that further research into the likelihood of $\mathrm{C}, \mathrm{B}, \mathrm{R}$, or $\mathrm{N}-$ rather than the previously emphasized likelihood of CBRN as a category compared with conventional terrorism-will be fruitful.

Ultimately, these findings support policy action in accordance with what Koblentz (2011) describes as "pragmatic" - as opposed to optimistic and pessimistic - prescriptions for CBRN terrorism. While the threat of CBRN terrorism is real, the lack of predictability for serious attack weapon type based on existing knowledge makes it difficult to tailor security responses to particular CBRN outcomes. Rather, policymakers should "provide protection against a broad spectrum of deliberate and national hazards" and 
address "the conditions that enable terrorists to pursue CBRN weapons" (Koblentz, 2011, p. 504). Furthermore, policymakers would be wise to consider the evidence provided in this paper against the technological determinist hypothesis for serious CBRN incidents: as long as policymakers adhere to these beliefs, they will be more susceptible to believing hoaxes and pranks informed by the same logic. If technological determinism performed historically to induce terrorists' use of CBRN weapons, globalized networks and economies - that is, Asal, Ackerman, and Rethemeyer's (2012) "economic embeddedness" effect - have spread to such an extent that relying on these explanations to inform policy is unlikely to generate favourable outcomes.

About the Author: Nicole Tishler is a second year Ph.D. student at the Norman Paterson School of International Affairs. She can be reached at: nicole.tishler@carleton.ca

\section{References}

Ackerman, G. (2009). Defining knowledge gaps within CBRN terrorism research. In M. Ranstorp \& M. Normark (Eds.), Unconventional Weapons and International Terrorism (pp. 13-26). London and New York: Routledge.

Asal, V. H., Ackerman, G. A., \& Rethemeyer, R. K. (2012). Connections can be toxic: Terrorist organizational factors and the pursuit of CBRN weapons. Studies in Conflict \& Terrorism, 35(3), 229-254.

Committee on Advances in Technology and the Prevention of Their Application to Next Generation Biowarfare Threats. (2006). Globalization, biosecurity, and the future of the life sciences. Washington, DC: National Academic Press.

Coyle, J. (2012). Optimization of nuclear, radiological, biological, and chemical terrorism incidence models through the use of simulated annealing Monte Carlo and iterative methods. (Masters thesis). Retrieved from Georgia Institute of Technology SMARTech Library. (http://hdl.handle.net/1853/43599)

Ferguson, C. D., \& Potter, W. C. (2004). The four faces of nuclear terrorism. Monterey, CA: Monterey Institute - Center for Nonproliferation Studies, Monterey Institute of International Studies.

Government of Canada. (2011). Chemical, biological, radiological, nuclear and explosives resilience strategy for Canada. Ottawa: Government of Canada.

Ivanova, K., \& Sandler, T. (2006). CBRN incidents: Political regimes, perpetrators, and targets. Terrorism and Political Violence, 18(3), 423-448.

Ivanova, K., \& Sandler, T. (2007). CBRN attack perpetrators: An empirical study. Foreign Policy Analysis, 3, 273-294.

Kilberg, J. (2011). Organizing for destruction: How organizational structure affects terrorist group behaviour. (Unpublished doctoral dissertation). Carleton University, Ottawa, ON.

Kilberg, J. (2012). A basic model for explaining terrorist group organizational structure. Studies in Conflict and Terrorism, 35(11), 810-830.

Koblentz, G. D. (2011). Predicting peril or the peril of prediction? Assessing the risk of CBRN terrorism. Terrorism and Political Violence, 23(4), 501-520.

Marshall, M. G., \& Jaggers, K. (2011). Polity IV project: Political regime characteristics and transitions: 1800-2011. [Data file]. Integrated Network for Societal Conflict Research (INSCR) Program, Center for International Development and Conflict Management (CIDCM), University of Maryland.

Mickolus, E. F., Sandler, T. Murdock, J. M., \& Flemming, P. A. (2006). International terrorism: Attributes of terrorist events (ITERATE): 1968-2006. [Data file]. Dunn Loring, VA: Vinyard Software.

Monterey Terrorism Research and Education Program. (2012). Monterey weapons of mass destruction terrorism database. Monterey, CA: Monterey Institute of International Studies. 
National Consortium for the Study of Terrorism and Responses to Terrorism (START). (2011). Global terrorism database. [Data file]. Retrieved from http://www.start.umd.edu/gtd

Nuclear Threat Initiative (NTI). (2012). Nuclear materials security index. Retrieved from http://www.ntiindex.org/

Political Risk Services (PRS) Group. (2012). International country risk guide. [Data file]. Retrieved from http://www.prsgroup.com/icrg.aspx

Rowlands, D., Littlewood, J. \& Kilberg, J. (2012). CBRN terrorism: Assessing the threat of CBRN terrorism by groups and individuals in Canada and worldwide. (Unpublished manuscript). Norman Paterson School of International Affairs, Ottawa.

Smithson, A. E. (2009). "Indicators of chemical terrorism." In M. Ranstorp \& M. Normark (Eds.), Unconventional Weapons and International Terrorism (pp. 67-94). London and New York: Routledge.

Tucker, J. B. (2000). Toxic terror: Assessing terrorist use of chemical and biological weapons. Cambridge, MA: MIT Press.

World Bank. (2012). World development indicators. [Data file]. Retrieved from http://data.worldbank.org/data-catalog/world-development-indicators

World Trade Organization. (2012). Time series on international trade. [Data file]. Retrieved from http://stat.wto.org/Home/WSDBHome.aspx?Language $=\mathrm{E}$

Yusufzai, R. (1999, January 11). Conversation with terror. TIME. Retrieved from http://www.time.com/time/magazine/article/0,9171,17676,00.html 
Vol. 2, Iss/Num. 2, Fall/Automne 2013

\section{Appendix:}

Table A1: Summary Statistics for Measures of CBRN-Related Industry

\begin{tabular}{|l|c|c|c|c|c|}
\hline \multicolumn{1}{|c|}{ Variable } & $\begin{array}{c}\text { Observations } \\
\text { (missing } \\
\text { values) }\end{array}$ & Mean & $\begin{array}{c}\text { Standard } \\
\text { Deviation }\end{array}$ & Minimum & Maximum \\
\hline bioindustry & $\begin{array}{c}1278 \\
(153)\end{array}$ & $1.33 \mathrm{e}+10$ & $1.33 \mathrm{e}+10$ & 5147 & $7.03 \mathrm{e}+10$ \\
\hline chemindustry & $\begin{array}{c}1378 \\
(53)\end{array}$ & $4.77 \mathrm{e}+10$ & $4.22 \mathrm{e}+10$ & 104571 & $1.64 \mathrm{e}+11$ \\
\hline nuclearindustry & $\begin{array}{c}1425 \\
(6)\end{array}$ & .8140351 & .3892149 & 0 & 1 \\
\hline radindustry & $\begin{array}{c}1319 \\
(112)\end{array}$ & $1.39 \mathrm{e}+10$ & $3.13 \mathrm{e}+10$ & 0 & $1.19 \mathrm{e}+11$ \\
\hline $\begin{array}{l}\text { log(chemindustry } \\
\text { /bioindustry) }\end{array}$ & $\begin{array}{c}1278 \\
(153)\end{array}$ & 1.658799 & .8669452 & -1.169022 & 9.735541 \\
\hline $\begin{array}{l}\text { (radindustry } \\
\text { /bioindustry) }\end{array}$ & $\begin{array}{c}1197 \\
(234)\end{array}$ & 35.97924 & 157.9776 & 0 & 2311.407 \\
\hline
\end{tabular}

Table A2: Summary Statistics for Measures of States' Regulatory Capacity

\begin{tabular}{|l|c|c|c|c|c|}
\hline \multicolumn{1}{|c|}{ Variable } & $\begin{array}{c}\text { Observations } \\
\text { (missing } \\
\text { values) }\end{array}$ & Mean & $\begin{array}{c}\text { Standard } \\
\text { Deviation }\end{array}$ & Minimum & Maximum \\
\hline industryreg & $\begin{array}{c}1425 \\
(6)\end{array}$ & 70.69053 & 14.96852 & 16 & 100 \\
\hline bureauqual & $\begin{array}{c}1368 \\
(63)\end{array}$ & 3.435459 & 1.021634 & 0 & 4 \\
\hline
\end{tabular}

Table A3: Summary Statistics for Previously Identified Controls

\begin{tabular}{|l|c|c|c|c|c|}
\hline \multicolumn{1}{|c|}{ Variable } & $\begin{array}{c}\text { Observations } \\
\text { (missing } \\
\text { values) }\end{array}$ & Mean & $\begin{array}{c}\text { Standard } \\
\text { Deviation }\end{array}$ & Minimum & Maximum \\
\hline gdppc & $\begin{array}{c}1409 \\
(22)\end{array}$ & 23.46556 & 14.7182 & .1394099 & 50.06353 \\
\hline techdev & $\begin{array}{c}1385 \\
(46)\end{array}$ & 5.370031 & 2.84183 & .1573904 & 10.40798 \\
\hline corruption & $\begin{array}{c}1360 \\
(71)\end{array}$ & 3.665594 & 1.14898 & 0 & 6 \\
\hline $\log ($ polity2) & $\begin{array}{c}1303 \\
(128)\end{array}$ & 2.182019 & .3430105 & 0 & 2.302585 \\
\hline religious & $\begin{array}{c}1431 \\
(0)\end{array}$ & .0761705 & .2653635 & 0 & 1 \\
\hline transnational & $\begin{array}{c}1431 \\
(0)\end{array}$ & .1516422 & .3587991 & 0 & 1 \\
\hline
\end{tabular}


Table A4: summary of Control Variables Collected Based on Previous Studies'

\begin{tabular}{|c|c|}
\hline Variable Name & Results from Previous Studies (CBRN vs. Conventional Attack) \\
\hline $\begin{array}{l}\text { Country Wealth } \\
(g d p p c)\end{array}$ & Significant positive predictor of CBRN (Ivanova and Sandler, 2007) \\
\hline $\begin{array}{l}\text { Democracy } \\
\text { (polity2) }\end{array}$ & $\begin{array}{l}\text { Significant positive predictor of CBRN (Ivanova and Sandler, 2007). Note: While } \\
\text { Asal, Ackerman, and Rethemeyer (2012) use the polity2 score, Ivanova and Sandler } \\
\text { (2006; 2007) use only Polity's "institutionalized democracy" variable. Polity } 2 \text { is } \\
\text { used here since, as a combination of democracy and autocracy elements, it is more } \\
\text { comprehensive than the democracy score alone. Furthermore, it converts instances } \\
\text { of "standardized authority scores" (i.e. - } 66 \text { for foreign "interruption"; - } 77 \text { for cases } \\
\text { of anarchy; and - } 88 \text { for transitional periods) to conventional scores, therefore not } \\
\text { negatively skewing results or requiring the elimination of observations for which } \\
\text { standardized scores are recorded from the analysis. }\end{array}$ \\
\hline $\begin{array}{l}\text { Corr } \\
\text { (corr }\end{array}$ & $\begin{array}{l}\text { found to be a significant negative } \\
\text { 2007) }\end{array}$ \\
\hline $\begin{array}{l}\text { Technological } \\
\text { Development } \\
\text { (techdev) }\end{array}$ & $\begin{array}{l}\text { Asal, Ackerman and Rethemeyer (2012) did not find significant results for this } \\
\text { measure, on the assumption that its effects were subsumed under their "McDonald's } \\
\text { Effect" measure for a country's embeddedness in the global economy. Since that } \\
\text { measure was publically unavailable over the period of time required, this variable is } \\
\text { used in its place. }\end{array}$ \\
\hline $\begin{array}{l}\text { Perpetrator - } \\
\text { Religious } \\
\text { Motivation } \\
\text { (religious) }\end{array}$ & $\begin{array}{l}\text { Ivanova and Sandler (2007) found that religious cults were a large and significant } \\
\text { predictor of CBRN attacks. However, these findings are based on a flawed } \\
\text { methodology, and false distinction between religiously-motivated cults and } \\
\text { fundamentalists (of the } 314 \text { observations under study, only } 28 \text { were perpetrated } \\
\text { by cults, and all but one were perpetrated by a single cult: Aum Shinrikyo. It is } \\
\text { misleading to extrapolate findings from this group to the entire category of } \\
\text { religious cults). This measure thus includes all religiously-motivated actors. }\end{array}$ \\
\hline $\begin{array}{l}\text { Perpetrator - } \\
\text { Transnational } \\
\text { Orientation } \\
\text { (transnational) }\end{array}$ & $\begin{array}{l}\text { Ivanova and Sandler (2007) found transnational orientation to be a significant } \\
\text { predictor of CBRN only for religious fundamentalists (they introduce an interaction } \\
\text { term that multiplies transnational orientation with religious motivation - it is not } \\
\text { significant when looking only within CBRN attacks) }\end{array}$ \\
\hline
\end{tabular}


Table A5: Results for Logit Regression on Hoaxes and Pranks and Multinomial Regression on Serious Incidents

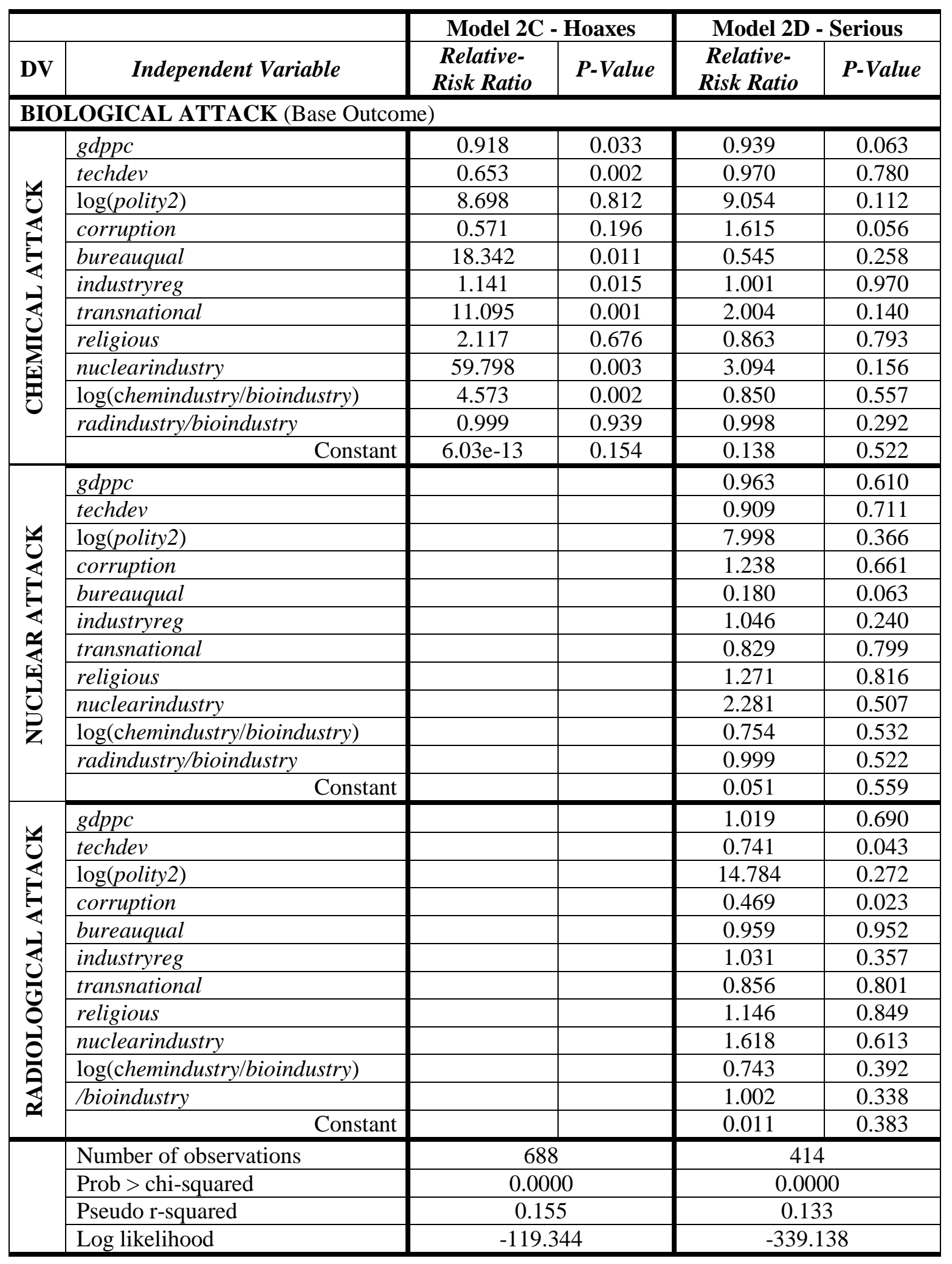


Vol. 2, Iss/Num. 2, Fall/Automne 2013 